\title{
ПУТЕШЕСТВИЕ ПО ВРЕМЕНАМ ГОДА
}

\author{
Франк Лидия Владимировна \\ учитель-дефектолог \\ высшей квалификационной категории \\ Краевой центр психолого-медико-социального \\ сопровождения, г. Красноярск
}

\begin{abstract}
Аннотация: Вашему вниманию предлагается подборка занятий по ознакомлению с окружающим миром для детей старшего дошкольного возраста с проблемами в развитии - по временам года -, из опыта работы педагога. Конспекты занятий обобщают и систематизируют знания детей, способствуют обогащению их словарного запаса, усвоению грамматических категорий, развитию связной речи.

Ключевые слова: Время года, осень, приметы осени, ранняя осень, золотая осень, поздняя осень, перелетные птицы, листопад, заморозки, разноцветные зонты, зима, приметы зимы, снег, лес, зимний лес, следы, сугроб, кора, животные зимой, весеннее настроение, весна, ранняя весна, признаки весны, сосулька, капель, ручей резвый, ручей, подснежник, лучистое солнышко, воробьи.
\end{abstract}

\section{A JOURNEY THROUGH THE SEASONS}

\section{Frank Lydia Vladimirovna}

Abstract: We offer you a selection of classes on familiarization with the surrounding world for older preschool children with developmental problemsaccording to the seasons-from the experience of the teacher. Lesson notes summarize and systematize children's knowledge, contribute to the enrichment of their vocabulary, the assimilation of grammatical categories, and the development of coherent speech.

Key words: Season, autumn, signs of autumn, early autumn, golden autumn, late autumn, migratory birds, leaf fall, frost, colorful umbrellas. Season, winter, signs of winter, snow, forest, winter forest, tracks, snowdrift, bark, animals in winter. Time of year, spring, early spring, signs of spring, icicle, drops, droplets 


\section{СОВРЕМЕННОЕ ОБРАЗОВАНИЕ: ОПЫТ ПРОШЛОГО, ВЗГЛЯД В БУДУЩЕЕ}

shimmer with different lights, the stream is frisky, the stream runs, hurries, murmurs, snowdrop, radiant sun, sparrows chirp merrily.

\section{Путешествие по осени.}

Цели:

Закрепить с детьми время года осень, характерные приметы осени; дать понятие о периодах осени (ранняя, золотая, поздняя). Продолжать знакомить с нетрадиционными приемами рисования (по трафарету, кусочком поролона).

Корригировать зрительную память, слуховое внимание через умение слышать, запоминать, ответить на вопрос; развивать общую и мелкую моторику, правильное дыхание через игровые упражнения, игру; корригировать цветовосприятие через самостоятельный выбор цвета краски при работе с трафаретом.

Воспитывать интерес к познавательной деятельности, занятию, эмоциональную адекватность (учить выражать радость, удовольствие), аккуратность, бережное отношение к материалу, доброжелательность, чувство коллективной солидарности.

\section{Оборудование и материалы:}

Иллюстрации по приметам осени, по периодам осени; листочки на ниточках для поддувания; зонтики по количеству детей и педагогу; кукла осень; веревочки (скакалки) для изображения луж на полу;

лист плотной бумаги (по количеству детей), трафареты зонтов (по количеству детей), по шесть тампонов на каждого ребенка, разведенная гуашь (12 цветов), салфетка на каждого ребенка;

магниты, магнитная доска; столы, стулья по количеству детей.

\section{Ход занятия:}

I. Организационный момент:

- Здравствуйте, ребята! Вместе со мной к вам пришла девочка-осень. Она приглашает нас с вами на прогулку. Но сначала давайте познакомимся! Здравствуй, Осень, меня зовут Лидия Владимировна, а это наши дети (передаю куклу следующему ребенку, он называет имя и так всем детям). Вот и познакомились! Давайте улыбнемся друг другу.

II. Сообщение темы занятия:

- Скажите, дети, сейчас какое время года? (осень). Давайте скажем, какая погода осенью? 
Д/и «Скажи, какая погода?». Если на улице ветер, то погода ветреная. Если пасмурно ...; если сыро...; если дождь....; если хмуро .... Осенью погода часто дождливая, вот я и взяла зонтик, чтобы не промокнуть, если пойдет дождь.

III. Беседа по теме:

- Беритесь за руки и пойдемте гулять вместе с Осенью. Какие лужи, делайте шире шаг, перешагивайте лужи, а эту лужу обойдем. Ой, какая грязная дорожка, никак ее не обойти, давайте пройдем на носочках.

Останавливаются на «полянке». Проводится беседа с детьми.

- Еще совсем недавно было лето (показ картинки). Что мы делали летом? (ответы детей). После лета наступила ранняя осень (показ картинки с изображением ранней осени). Листья на деревьях почти все зеленые. Только начинают желтеть. Еще довольно тепло, даже жарко бывает днем. Но к вечеру становится прохладно. Днем солнышко еще пригревает, но часто дует холодный ветер, на небе появляются тучи, и идут дожди. Дни становятся короче, а ночи длиннее и намного холоднее, чем летом. Ранней осенью одни перелетные птицы, собравшись в стаи, улетают в теплые края (ласточки). Другие - еще только готовятся к отлету (гуси, грачи, журавли).

Детям задаются вопросы, для закрепления материала. Какая эта осень? Какие листья на деревьях? Что делают перелетные птицы?

- После ранней осени наступает осень золотая. Посмотрите на эту картинку. Все листья на деревьях, кустарниках становятся разноцветными, усиливается листопад, вянет и желтеет травка, небо чаще серое, чем голубое, часто идут дожди. По утрам бывают легкие морозцы - заморозки. Продолжают улетать в теплые края перелетные птицы.

Задаются вопросы по закреплению материала. Как называется эта осень? Какие на деревьях листья? Какая трава?

- Посмотрите на следующую картинку (показ картинки). После золотой осени наступает поздняя осень. Поздней осенью совсем холодно, ветрено, пасмурно, дождливо. С деревьев и кустов облетают все листья, засыхает травка, улетают все перелетные птицы, иногда выпадает снег.

Закрепляется данный детям материал. А эта осень как называется? Какие деревья стоят? Что на небе? Какая сейчас у нас осень?

- Ой, посмотрите какие листочки нам принес ветер! Давайте поиграем с ними! (Выполняется упражнение на развитие речевого дыхания - за ниточку 


\section{СОВРЕМЕННОЕ ОБРАЗОВАНИЕ: ОПЫТ ПРОШЛОГО, ВЗГЛЯД В БУДУЩЕЕ}

держат листочек и дуют: воздух вдыхают через нос, а выдыхают через рот, делая губы трубочкой, не надувая щек).

- Вот ветер подул сильнее, все небо покрылось тучами, и пошел дождь. Сначала мелкий, давайте поиграем с капельками. Приготовьте ладошки.

Капля раз, капля два, Дети имитируют ловлю ладошками капель

Капля медленно сперва дождя в медленном темпе.

Кап, кап, кап, кап. Хлопки в ладоши в медленном темпе.

Стали капли поспевать, Дети имитируют ловлю ладошками капель

Капля каплю подгонять. Дождя в быстром темпе.

Кап, кап, кап, кап. Хлопки в ладоши в быстром темпе.

- Ой, какой сильный дождь пошел! Бегите скорей под зонтик! (педагог раскрывает зонт, дети бегут под зонт). Зонтик нам очень нужен осенью!

- Вот и прошел дождь! Но сколько луж! (из скакалок). Ребята, Осень предлагает посетить выставку зонтов. Пойдем? Беремся за руки и пойдем аккуратно, чтобы не замочить ноги. (Обходят лужи - скакалки, выложенные разными формами).

Дети подходят к раскрытым зонтам, рассматривают зонты, рассказывают о них (каждый ребенок об одном выбранном зонте).

Педагог: Кругом цветные зонтики, раскрылись под дождем,

Пустились чьи-то ботики от дождика бегом!

Ребята, Осень спрашивает, нравятся - ли вам зонтики? Предлагает вам изготовить свои зонтики кто, какой хочет! Посмотрите: это шаблоны вырезанных из белого картона зонтиков. Возьмите по - одному зонтику и раскрасьте красками, как хотите, используя эти штампы!

Идет объяснение процесса работы. Обращается внимание на приготовленные атрибуты. Дети выполняют задание, педагог оказывает помощь детям, по мере необходимости.

Ребята, Осень предлагает вам полюбоваться изготовленными зонтиками: дети подходят к каждой работе и оценивают ее. Приходят к выводу, что получились разнообразные, разноцветные, красочные, красивые зонтики.

IV. Итог занятия.

Педагог с куклой - осенью в руках: пока сохнут наши зонтики, подойдите ко мне. Давайте вспомним, что мы делали сегодня? Что узнали об осени? Какая она бывает? В какие игры играли? Что еще делали? 


\section{СОВРЕМЕННОЕ ОБРАЗОВАНИЕ: ОПЫТ ПРОШЛОГО, ВЗГЛЯД В БУДУЩЕЕ}

Понравилось вам занятие? (отмечается каждый ребенок за что-либо хорошее). Молодцы!

А теперь возьмите свои зонтики на память о нашей встрече. До свидания! До новых встреч! Будьте здоровы!

\section{Прогулка в зимний лес.}

\section{Цели:}

1. Обобщить и систематизировать знания детей о зиме, ее приметах, жизни животных зимой;

2. Развивать долговременную память через припоминание ранее изученного материала; развивать произвольное внимание через выполнение упражнений в музыкальном круге и пальчиковой игре; расширять активный словарь через подбор однокоренных слов, слов прилагательных;

3. Воспитывать интерес к окружающему, любовь и бережное отношение к природе.

\section{Оборудование и материалы:}

Платье - шубка для педагога; компьютер; слайд-шоу с музыкальным сопровождением; магнитная доска; игрушки (медведь, заяц); конверт с письмом; красочная коробка с сюрпризом; бумажные снежинки на ниточках для поддувания; снежинки (из бумаги); зимнее дерево (из ватмана); рукавички по количеству детей и педагогу с картинками однокоренных слов о зиме; картинки медведя, зайца с их следами; бросовый материал - пробки, для составления снеговика; белая салфетка из ткани с нарисованным изображением снеговика; картинки с изображением зимних забав, примет зимы; опорные элементы для составления зимней картины.

\section{Ход занятия:}

I. Организационный момент:

Звучит музыка. Входит педагог с детьми. Находят около двери снежинки.

Педагог (берет одну снежинку): «Дети, что это такое? (ответы детей). Какое сейчас время года? (ответы детей). Назовите приметы зимы. Вот и к нам снежинки залетели. Педагог обращает внимание детей на конверт, предлагает открыть его. В конверте письмо: « давайте прочтем!»

«Здравствуйте, дорогие ребята! Я предлагаю вам прогуляться в зимний лес. Отправляю вам подарок! Но сначала выполните мои задания. Я их 


\section{СОВРЕМЕННОЕ ОБРАЗОВАНИЕ: ОПЫТ ПРОШЛОГО, ВЗГЛЯД В БУДУЩЕЕ}

развесила для вас на Чудо-дереве. Путь к дереву вам укажут снежинки. Желаю вам успехов. Ваша Зима».

Педагог: Ребята, что такое лес? (выяснят вместе с детьми). А, вот снежинки. Давайте подуем на них (выполняется дыхательная гимнастика дети дуют на снежинки, которые раздает им педагог). Разлетелись наши снежинки, приглашают нас на прогулку в зимний лес! Надо теплее одеться! Ведь зимой очень холодно на улице!

Звучит сказочная музыка.

Игра - имитац̧ия «Оденемся на улицу».

Спит земля глубоким сном,

Ну а мы гулять пойдем.

Наденем на ножки, теплые сапожки.

Этот с правой ножки, этот с левой ножки.

Шапочки пуховые, шубки меховые.

Застегнем все пуговицы.

Вот так. Вот так.

Пуговка к пуговке в ряд.

На ручки - рукавички -

Теплые сестрички.

В эту правый кулачек,

В эту левый кулачек.

Раз, два, три, четыре, пять,

Мы пойдем гулять.

Педагог: «Готовы? Тогда пойдемте! (идут по снежинкам).

Мы шли, шли, шли

По сугробам шли, шли,

К Чудо-дереву пришли!

Группа оформлена как лес: стоят деревья в снегу, развешаны снежинки.

Педагог: Посмотрите, дети, куда нас привели снежинки? Что вы видите? (ответы детей). Да, дети, это зимнее дерево. Но оно еще и волшебное! Посмотрите, сколько на нем разноцветных снежинок! (рассматриваем). Но не только разноцветные снежинки на нем, еще зима развесила задания для вас! (снимает конверт, в нем - белая рукавичка с изображением снежинки).

- Давайте посмотрим - куда полетит снежинка? (педагог надевает рукавичку с изображением снежинки и выполняется зрительная гимнастика). 


\section{СОВРЕМЕННОЕ ОБРАЗОВАНИЕ: ОПЫТ ПРОШЛОГО, ВЗГЛЯД В БУДУЩЕЕ}

- А, что же в этом конверте? (рукавички, с изображением однокоренных слов на каждого ребенка (снежинка, снеговик, снегурочка, снег), дети надевают на руку, приходят к выводу, что все слова похожи на слово «снег»). - Молодцы, дети! (снимает следующий конверт)

- Посмотрите, ребята, а это что? (показывает картинки медведя и зайца с их следами, рассматривают, выясняют, чьи это следы, где живут звери), зима предлагает пойти в зимний лес на прогулку (следы медведя походкой медведя, зайца походкой зайца).

Педагог: Посмотрите, какие деревья в лесу! (слайды с изображением зимних деревьев с музыкальным сопровождением). Что на них лежит? рассматривают («снег»; дети подбирают прилагательные к слову «снег», какой он). Да, дети, на деревьях лежит белый, холодный, пушистый, сверкающий, легкий снег. Какой красивый зимний лес: все белым-бело! Никого не видно. Все как будто спит. Даже зверушки и те попрятались. Посмотрите, что это? Какой большой сугроб! Ой, там кто-то есть! Кто там? (медведь). Что делает зимой медведь? (ответы детей). Верно, он спит зимой. А, когда он проснется? (ответы детей) - Медведь проснется, когда наступит весна, пригреет солнышко, начнет таять снег.

- Повторяйте за мной стихотворение про медведя и выполняйте движения!

Как на горке - снег! Снег!

И под горкой - снег! Снег!

И на елке - снег! Снег!

И под елкой - снег! Снег!

А под снегом спит медведь.

Тише, тише - не шуметь!

(произносят четверостишье с элементами пальчиковой гимнастики).

- Пойдемте тихо, чтобы не разбудить мишку! (слайды с зимним лесом). Вот какой красивый лес! Как много деревьев! И все они в снегу! Красиво как в сказке, дети!

- А вот заячьи следы, давайте попрыгаем как зайчики! А вот и он сам! Дети, около какого дерева он сидит? (береза).

Педагог (берет зайку в руки): «Зайка, здравствуй! Ты что так трясешься? Кого же ты боишься в лесу? Не бойся. Это добрые ребята» (дети успокаивают зайку, передавая из рук в руки). 


\section{СОВРЕМЕННОЕ ОБРАЗОВАНИЕ: ОПЫТ ПРОШЛОГО, ВЗГЛЯД В БУДУЩЕЕ}

Педагог: «Посмотрите, какая у зайца шубка? (ответы детей). А, летом, каким цветом была шубка у зайца? Почему он поменял шубку? (ответы детей). Посмотрите, выпал белый снег. В лесу много снега. Снег белый и шубка белая. Не увидят волк и лиса белого зайца на белом снегу.

А есть ли домик у зайца? (он живет под кустиками). Что он любит есть? (ответы детей). А зимой в лесу заяц ест кору, веточки с деревьев. Что ест заяц зимой в лесу? (ответы детей)».

Заяц: «Какие вы умные, ребята! А вы играть любите? Я интересную игру знаю. Хочу поиграть с вами. Сначала я превращу вас в зайчат.

Влево, вправо повернись

И в зайчонка превратись!»

(педагог надевает детям наголовники с изображением зайцев).

Дети - зайчата встают в кружок.

Заяц: «А я вас буду догонять!»

Дети: «Зайки белые сидят

Ушки длинные торчат.

Вот такие ушки,

Ушки на макушке! (показывают ушки руками)

Сели зайки в кружок

Роют лапкой корешок.

Вот такие лапки -

Острые царапки! (выполняют движения кистью руки)

Заяц: «А теперь я к вам бегу!

Убегайте, зайки,

Зайки - побегайки!» (педагог с зайкой в руках догоняет детей)».

Заяц: «Где же вы, зайки? (зайка ловит детей). Молодцы, быстро бегаете!

Влево, вправо, повернись

В ребятишек превратись!

Педагог: Дети, давайте попрощаемся с зайкой, угостим его морковкой (угощают морковкой, прощаются)

- Посмотрите, как много снега! (на слайдах). А, вы знаете, во что можно играть зимой? (ответы детей, показ картинок).

- има предлагает вам поиграть - сделать снеговиков, (педагог раздает каждому ребенку ткань, с нарисованным изображением снеговика, мешочек с 


\section{СОВРЕМЕННОЕ ОБРАЗОВАНИЕ: ОПЫТ ПРОШЛОГО, ВЗГЛЯД В БУДУЩЕЕ}

пробками; объясняет, как выполнить очередное задание зимы). Какие замечательные снеговики получились! Молодцы!

- И, вот, последнее задание: Вспомнить, о чем говорили, что видели и составить картинку.

Совместно с педагогом дети вспоминают и выставляют на доску опорные элементы, проговаривают.

Педагог: Посмотрите, дети, о каком времени года получилась наша картина? (ответы детей).

Педагог подытоживает сказанное, называет признаки зимы.

Педагог: Молодцы! Вот мы и выполнили все задания Зимы! (дает оценку каждому ребенку). А, вот и подарок вам от Зимы! (достает красочную коробку, спрятанную под «снегом» около чудо дерева, угощает детей).

- Как было приятно нам прогуляться по зимнему лесу! Скажем до свидания ему!

\section{Весеннее настроение.}

\section{Цели:}

1. Учить детей знать и называть время года весна, выделять основные признаки ранней весны, учить составлять рассказ о весне по картинке по наводящим вопросам. Активизировать словарный запас по теме ранняя весна (сосулька, капель, ручей, подснежник)

2. Корригировать долговременную память, через заучивание и воспроизведение стихов потешек, развитие зрительного восприятия через составление общей картины о весне, художественное оформление, коррекция эмоционального и мышечного напряжения через музыкальное сопровождение и релаксацию

3. Воспитывать интерес к окружающему, умение работать в коллективе через различные виды совместной деятельности

\section{Оборудование и материалы:}

CD-диск Звуки природы «Воздушные потоки», И.Штраус «Весенние голоса», художественное оформление (изображение весеннего пейзажа), предметы для составления картинки о весне, колокольчики (на каждого ребенка), металлофон, ленточки (на каждого ребенка) для изображения ручейка, бумажная лодочка, емкость с водой, наголовники воробьев (на каждого ребенка), игрушка кошка, обруч (гнездо).

\section{Ход занятия:}




\section{СОВРЕМЕННОЕ ОБРАЗОВАНИЕ: ОПЫТ ПРОШЛОГО, ВЗГЛЯД В БУДУЩЕЕ}

Организационньй момент:

Звучит музыка И. Штрауса «Весенние голоса».

Дети! Скажите мне, в какое время года бывает то, о чем я загадаю загадку:

Тает снежок,

Ожил лужок

День прибывает

Когда это бывает? (весной)

Правильно, весной. Какое сейчас время года? (весна). Сегодня мы с вами будем говорить о весне и составлять весеннюю картинку. Вспомните, какие стихи о весне мы учили? (дети рассказывают ранее выученные стихи о весне).

Пришла весна. Еще лежит снег, но что можно сказать о солнце? Закройте глаза. Вспомните, как мы гуляли, наблюдали за солнцем. Релаксация. Протяните ладони, подставьте лицо. Вот солнышко согрело ладони, согрело лицо деток... Тепло вам? Открывайте глазки. Скажите: какое солнышко? (теплое, лучистое). Что делает солнышко: (светит, греет). Вы рады солнышку? Я тоже рада солнышку, все рады теплу. Весной солнце светит все ярче и ярче. Зовут люди солнышко, чтобы скорее наступило тепло, трава и листочки зазеленели. А вы хотите, чтобы снег растаял, трава и листочки зазеленели? (да). Давайте тоже позовем солнышко. Вставайте в круг, в хоровод (дети произносят потешку, взявшись за руки, идя по кругу).

Солнышко-солнышко! Выгляни в окошко!

Ждут тебя детки, ждут малашечки.

Солнышко-ведрышко. Выгляни в окошечко.

Твои детки плачут, по камушкам скачут.

Солнышко, покажись! Красное, появись!

Будем звать солнышко каждый день. Солнышко нас услышит, и весна будет солнечной, теплой, быстрее растает снег.

О чем мы сейчас говорили? (о солнце). Давайте на нашу картину о весне поместим солнышко.

Звучит музыка А. Александрова «Капель».

Дети, что вы слышите? (дети прислушиваются, слышат звон капели). Что вы слышите? (падают капельки) А откуда падают капельки (сосульки тают). Почему сосульки тают? (весна пришла, солнышко пригрело). А давайте 


\section{СОВРЕМЕННОЕ ОБРАЗОВАНИЕ: ОПЫТ ПРОШЛОГО, ВЗГЛЯД В БУДУЩЕЕ}

возьмем колокольчики и сыграем песенку капелек. Давайте по - одному позвеним колокольчиком (каждый ребенок по очереди звенит колокольчиком, педагог обращает внимание, что звон колокольчика - это падают капельки).

А теперь все вместе. Вот какая красивая песенка! Много капелек падает. Дон! Динь! День! С крыш, с прозрачных сосулек падают вниз капли - капкап-кап. Это капель. Что такое капель? (дети отвечают). О чем мы сейчас говорили? (о капели). Давайте на нашу картинку о весне поместим капельки (дети помещают).

Капельки вспыхивают под солнцем, переливаются красными, синими, желтыми огоньками. Кажется, что не холодная вода капает, а летят горячие, солнечные брызги. Педагог предлагает одному из детей прочесть стих: «Сосулька, сосулька! Капай веселей!»

А слышите, как весело чирикают воробьи? (в записи). Чему они обрадовались? (солнцу, весне, концу зимы). Воробьи искупались в этих капельках и зачирикали, запели по-весеннему радостно.

Педагог предлагает детям поиграть.

Подвижная игра «Кот и воробышки».

О ком мы сейчас говорили? (о воробышках). Что они делают? (радостно чирикают, купаются в лужицах). Давайте поместим на нашу картину о весне воробьев.

Звучит музыка А. Аренский «Лесной ручей».

Греет солнышко, греет, снег тает, сосульки тают, падают капли, и вот зазвучал чей-то голосок.... (дети узнают ручеек, находят его на картинках, показывают движением руки специфическое движение ручейка).

Педагог обращает внимание детей на картинку ручья. Ручеек озорной, резвый, быстрый, веселый, он бежит, спешит, течет, журчит. Дети сделали кораблики и стали пускать их.

Подвижная игра «Кораблики». Дети пускают друг другу бумажный кораблик в емкости с водой.

Давайте поместим наш кораблик на ручеек, пусть он плывет!

О чем мы сейчас говорили? (о ручейке). Какой он? (быстрый, озорной). Что он делает? (бежит, журчит, течет).

Давайте на нашу общую картину о весне поместим и ручеек.

Педагог предлагает следующему ребенку прочесть стих: «Уж тает снег». Хотите узнать - куда бежит ручеек? А давайте побежим вместе с ним. 


\section{СОВРЕМЕННОЕ ОБРАЗОВАНИЕ: ОПЫТ ПРОШЛОГО, ВЗГЛЯД В БУДУЩЕЕ}

Упражнение «Речек». Дети берут голубые ленточки и бегут по залу, педагог сопровождает упражнение чтением стихотворения Ф. Тютчева «Солнце ласково смеется».

Вот куда спешил наш ручеек! На поляну! (обращается внимание детей на деревья, на подснежники). На поляне в некоторых местах снег растаял, знаете почему? Солнце пригрело, снег тает, появляется земля, и из земли выросли первые весенние цветы - подснежники.

Как, дети, называются первые весенние цветы? (подснежники).

Педагог закрепляет с детьми название первого весеннего цветка (дети проговаривают). Они появились из-под снега, поэтому называются подснежники. Пригрело солнышко, растаял снег, отогрелась земля, и сразу появились первые весенние цветы - подснежники.

О каких цветах мы сейчас говорили? (о подснежниках).

Давайте на нашу общую картинку о весне поместим и подснежники.

\section{Итог занятия:}

Вот и получилась у нас картинка. О каком времени года мы составили картинку? (о весне). Давайте расскажем о весне.

(дети рассказывают о весне по наводящим вопросам).

Педагог отмечает работу каждого ребенка, благодарит их за активность, за участие и предлагает вспомнить выученную потешку о весне:

Дети встают по кругу, рассказывают потешку и выполняют движения.

А, уж ясно солнышко

Припекло, припекло. (руки вверх).

И повсюду золото

Разлило, разлило. (движения кистями рук).

Ручейки на улице

Все журчат, все журчат. (изображают руками движения ручейка).

Журавли курлыкают

И летят, и летят. (машут кистями рук как крыльями).

Расцвели подснежники

Да в леске, да в леске. (показывают кистями рук).

Скоро всей земелюшке

Быть в венке, быть в венке. (показывают венок на голове).

Ой, солнышко-батюшка

Угоди, угоди! (руки вверх). 


\section{СОВРЕМЕННОЕ ОБРАЗОВАНИЕ:

А, землица-матушка

Уроди, уроди! (поклон).

\section{Список литературы}

1. Арефьева Л.Н. Лексические темы по развитию речи детей $4-8$ лет, методическое пособие. - Творческий центр, М, 2005

2. Гербова В. В. Развитие речи в детском саду. - М., 2005

3. Калинченко А.В., Микляева Ю.В., Сидоренко В Н. Развитие игровой деятельности дошкольников. - М., 2004

4. Коноваленко В.В. Коррекционная работа воспитателя в старшей логопедической группе. - «Гном - Пресс», М, 2004

5. Кузнецова Е.В., Тихонова И.А. Развитие и коррекция речи детей 5 6 лет, сценарии занятий. Творческий центр, М, 2005

6. Микляева Н.В., Леонович Е.Н. Познавательное и речевое развитие дошкольников. Творческий центр 2015. 